\title{
Influence of Teacher Leadership and Professional Competency on the Academic Achievement of College Students in English Language in the Sultanate of Oman
}

\author{
Wahaybi Roqaia Humaid Ali ${ }^{8}(D) \triangle$, Mohamad Johdi Bin Salleh ${ }^{2}(D)$ and Mohd Burhan Bin Ibrahim ${ }^{3}$ (D) \\ ${ }^{123}$ International Islamic University, Malaysia
}

$\triangle$ Corresponding Author: Wahaybi Roqaia Humaid Ali, E-mail: Roqaia.wahaybi@gmail.com

\section{ARTICLE INFORMATION ABSTRACT}

Received: August 08, 2021

Accepted: September 10, 2021

Volume: 3

Issue: 9

DOI: $10.32996 /$ jweep.2021.3.9.1

\section{KEYWORDS}

Teacher Leadership, Professional Competency, Academic

Achievement, College Students,

Sultanate of Oman
This study investigated the relationship between teacher leadership and professional competency on student academic accomplishment in vocational colleges in Oman. A questionnaire was instructed and conducted from post foundation students across the seventh vocational colleges in the Sultanate of Oman to collect data. A quantitative research approach was adopted to analyze the data. Built on Kane's comprehensive framework of teacher leadership (2009); Fenollar, Roman and Cuestas' integrative model of the antecedents of academic performance (2007), the present study formulated a new framework to fit into the Omani context education. SPSS was used to analyze data. The study showed that all the main hypotheses of the study are accepted. The study concluded that there is a positive relationship between teacher leadership, professional competency and student academic performance in the English language. Such a positive relationship lies in that students are highly affected by their teachers' leadership skills and professional competencies. Future research is needed to investigate the relationship between teacher gender, age, experience, and qualification as independent variables and student academic performance at vocational colleges in the Sultanate of Oman.

\section{Introduction}

English is the second spoken language used after Arabic in the Sultanate. Nevertheless, in general, college students are not good enough at English and hence very few highly educated people are able to communicate in English. This is due to many factors, i.e. poor education curriculum, poor teacher training, and ineffective school management. The main problem that this study tries to investigate is that teacher leadership and professional competencies play an essential role in developing and enhancing student academic accomplishment at the college level. There is, in fact, a real problem to be investigated that a significant number of college students are not even able to have a short conversation. Therefore, this hinders their professional development at local and international levels, especially for those working for foreign companies and those willing to pursue their postgraduate studies. Al-Taneiji and Ibrahim (2017) reported that undergraduate students in the Sultanate of Oman are mostly incompetent in language except for a few having studied in schools and colleges where English is the main language of instruction. This incompetency is attributed to various factors: 1-general-related factors are related to mother tongue interference, native language dominance, culturally prevalent norms and stereotypes. Specific-related factors are associated with lack of attention on the Ministry of Higher education, poor training for ESL teachers, poor ESL syllabuses, poor organizational structure, lack of student competition, and insufficient incentives. Today, most scholars agree that (Ambusaidi \& Yang, 2019) ESL college instructors can make a substantive difference in student academic accomplishment if there are organized plans, wellstructured pedagogical schemes and extra-curricular activities. English education in the Sultanate needs studies to investigate the effects and roles of teacher leadership and professional competency in boosting motivational and metacognitive abilities and skills in students. Hence, "accounting for teacher effects remains a somewhat puzzling task" (Canales \& Maldonado, 2018, p: 94). Canales and Maldonado (2018) reported that it is essential for new research to examine how educator leadership and professional competency influence student academic accomplishment in the vocational colleges in Oman. In fact, the relationship between teacher leadership, professional competency and student academic achievement has not been yet

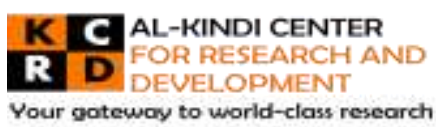

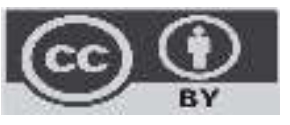

Published by Al-Kindi Center for Research and Development. Copyright (c) the author(s). This open access article is distributed under a Creative Commons Attribution (CC-BY) 4.0 license 
investigated in the Sultanate, for instance, (Al-Taneiji \& Ibrahim, 2017; Al-Zboon, 2016) reported that there is a very little research concerning the relationship between teacher leadership, professional competency and student academic performance in the English language at the vocational colleges in Arab countries. There is evidence that teachers and educators are encouraged to implement educational transformations (Koedel, Parson, Podgursky, \& Ehlert, 2015). Nevertheless, they, in most cases, lack courage to come up with new ideas for their inadequate knowledge and skills (Karami-Akkary \& Rizk, 2012).Today, most scholars agree that educators can make a substantive difference in students' academic accomplishments (Koedel, Parson, Podgursky, \& Ehlert, 2015). Extant literature requires more studies to investigate teacher effect and role in boosting students' motivational and metacognitive abilities and skills. Hence, "accounting for teacher effects remains a somewhat puzzling task" (Canales \& Maldonado, 2018, p:17). This research, thus, fills an essential previous research gap by demonstrating new evidence on the correlation between teacher leadership, professional competency and student academic achievement in the Sultanate of Oman.

Student academic achievement represents the extent to which an institution successfully achieves its goals and facilitates students' comprehensive development. Students who succeed in attaining high levels of achievement are more prepared for pursuing success in their professional lives. Therefore, supporting student academic achievement is a significantly important educational goal. Educators should pay special attention to improving student achievement in critically needed subjects in the $21^{\text {st }}$ century.

\section{Literature Review}

Recent research has addressed teacher quality emphasizes that teachers' contribution to student academic accomplishment diverges depending on many variables such as teacher professional and academic background, years of experience and classroom practices (Ambusaidi \& Yang, 2019). The empirical literature that analyzed predictors of student accomplishment has handled the issue of teacher quality leadership and impact by examining the influence of distinct teacher variables and examining the effect of the overall teacher quality (Korkmaz, 2017). It is reported that empirical studies associating teacher quality and leadership with student academic achievement are limited to pedagogical literature in Oman. Few studies have examined teacher quality and leadership characteristics associated with college student academic accomplishment in other countries (Akiba, LeTendre \& Scribner, 2007). Many studies shed light on previous research results related to teacher leadership quality variables that have positively affected student learning. Some empirical studies in the United States "have identified the characteristics of teacher quality that are associated with higher student achievement" (knight, 2012, p. 18). According to (Knight, 2012), two types of studies have been done to search the impact of teacher quality and leadership and their effect on student academic achievement. These types are divided into (a) studies examining variations in teacher effects by testing differences between classes in accomplishment gains after controlling specific background characteristics and (b) regression studies investigating the relationship between teacher characteristics and student accomplishment after controlling specific background characteristics (Darling, 2015). Teacher leadership and quality virtues are of positive significance with teacher's years of experience and students' intelligence quotient. Hanushek \& Rivkin (2006, p:16) stressed, for instance, that "a teacher's years of experience have a positive relationship with student learning, but it is not always significant or linear". Other studies have stressed that teachers with less experience (those with less than a three-year experience) are typically less effective than their senior counterparts. The present study may agree with these studies, yet teacher experience alone may not be the only criterion to be measured since teacher personal traits, social relationships, psycho-motivational skills, and cognitive capabilities are pivotal factors to include in the measurement process. Hence, some young teachers, for instance, could be far more accepted by students as well as administrative personnel than senior teachers. New future research is essential to discuss how such traits influence student academic achievement as well as their motivational level in and outside the classroom and school boundaries. Many researchers indicate that teacher professional development matters for teaching practices and for enhancing student academic achievement. Many studies concluded that educators' participation in sustained professional development is connected to the teachers' syllabus. This is associated with higher levels of student accomplishment in English language competencies (Wiley \& Yoon, 1993). The present study differs from Zuzovsky's study (2015) in that it shows a significant relationship between teacher leadership characteristics and student academic outcomes. Investigating the relation between school leadership and student academic achievement is necessary to avoid students' low achievement.

It was reported by many scholars that there is no fixed and definite way to define the concept of leadership. According to Cuban (1988, p.190), "there are more than 350 definitions of leadership but no clear and unequivocal understanding as to what distinguishes leaders from non-leaders". Developing a working definition of this elusive and complicated concept (leadership) has become of great significance. As asserted by Beare, Caldwell and Millikan (1992, p.99) "outstanding leadership has invariably emerged as a key characteristic of outstanding schools. There can no longer be a doubt that those seeking quality in education must ensure its presence and that the development of potential leaders must be given high priority" (Beare, Caldwell \& Millikan, 1992, p.35). 
Leadership is defined as "a process of interaction between leaders and followers in which leaders attempt to influence followers to achieve a common goal" (Yukl, 2008, p.57). Leadership as a theoretical term and the experimental concept was brought to the educational system in Oman in the last few decades. The emergence of school leadership as a catalyst for change in schools came emanated from the educational reform in Oman (Al-Harthi and Al-Mahdy 2017).

\section{Research Methodology}

\subsection{Theory and Conceptual Framework}

Having comprehensively reviewed the relevant models, the researcher of the present study has formulated a new framework to investigate the co-relationship between teacher leadership, academic proficiency and student academic accomplishment in the Sultanate of Oman. The framework of this study was built on Kane's comprehensive framework of teacher leadership (2009) and an integrative model of the antecedents of academic performance by Fenollar, Roman \& Cuestas (2007). The independent variable of the present study is 1-teacher leadership and professional competency, while dependent variables are student academic achievement. The main independent variables of this study include first that teacher leadership under which English instructors' skills, value and knowledge are to be tested at the vocational colleges in the Sultanate of Oman, and include second that teacher professional competency such as his/her academic and professional skills as well techniques that are to be tested. By considering the dependent and independent variables of the study, the researcher will test how the components of teacher leadership as an independent variable impact students' academic achievement as a dependent variable.

\subsection{Framework of the Study}

As aforementioned, the framework of this study was first adopted from other authors' works and then formulated and developed to fit into the educational environment in the Sultanate of Oman. In line with the framework, this study argues that independent variables such as teacher leadership traits and professional proficiency affect dependent variables such as student academic achievement.

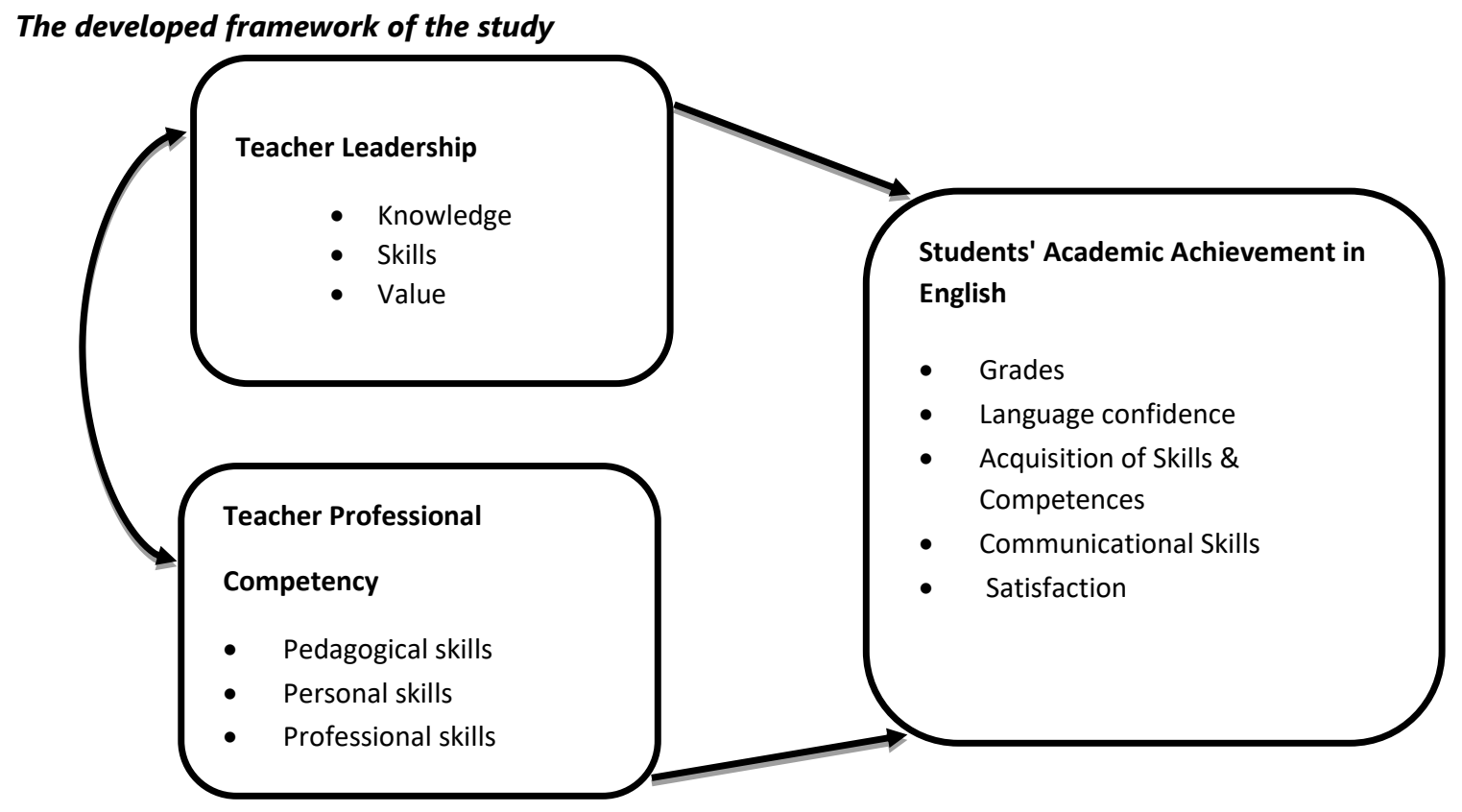

The study adopts a cross-sectional survey design to explore the relationship between teacher leadership, professional competency, and student academic achievement to collect the data. In this kind of research study, either the entire or a subset of the population is selected. Then only, data is gathered from these individuals.

The researcher could collect data from a broader sample of participants to produce numerical results by conducting a survey. This study adopts the primary quantitative research method and thus, a survey was used as a research tool to gather the data from 325 students from the seventh vocational colleges in the Sultanate.

The total number of final year students during the academic year (2019/2020) was 1721 (Ministry of Manpower, 2019). As demonstrated in table 3.2, students' number was distributed to different vocational colleges in different locations. These colleges are Seeb, Saham, Sur, Ibri, Shinas, Al-Buraimi and Salalahand, one vocational college for Marine Sciences (VMC) in AlKabourah. 
Table 3.2 Final Year Students at The Vocational Colleges During the Academic Year (2019/2020)

\begin{tabular}{|l|l|l|l|}
\hline Vocational College & Male & Female & Total \\
\hline Seeb & 216 & 291 & 507 \\
\hline Saham & 44 & 143 & 187 \\
\hline Sur & 66 & 109 & 175 \\
\hline Ibri & 36 & 134 & 170 \\
\hline Shinas & 31 & 84 & 115 \\
\hline Al-Buraimi & 24 & 94 & 118 \\
\hline Salalah & 271 & 178 & 449 \\
\hline Grand Total & $\mathbf{6 8 8}$ & $\mathbf{1 0 3 3}$ & $\mathbf{1 7 2 1}$ \\
\hline
\end{tabular}

In Salalah college, Table 3.2 demonstrates that female students outnumbered male students in the other six colleges. Seeb had scored the highest number of students, followed by Salalah. However, Shinas and Al-Buraimi had got the least number of students; 115 and 118 respectively.

The questionnaire consisted of 49 items carefully checked and edited. Participants were given clear instructions before responding to the questionnaire. To seek validity and reliability, the questionnaire was given to three experts in the field to assess.

\subsection{Items of Teacher Leadership Questionnaire}

The questionnaire items to measure teacher leadership were set up based on Teacher Leadership Instrument by (Yusof, Min, Jalil, Noor \& Yusof, 2018). The items for the first part of the questionnaire to erasure teacher leadership consist of three dimensions: knowledge, skill and value. Table 3.5 shows details about teacher leadership items.

\section{Table 3.5 Teacher Leadership Dimensions}

\begin{tabular}{|c|c|c|}
\hline Dimensions & Focus & Number of Items \\
\hline 1 Knowledge & $\begin{array}{l}\text { 1-Demonstrating knowledge for high-quality } \\
\text { professional learning. } \\
\text { 2-Assessing the development of the organization. } \\
\text { 3-Playing mentor and coach roles. } \\
\text { 4-Encouraging continuous development of the } \\
\text { students. } \\
\text { 5-Showing knowledge on students' diversity. } \\
\text { 6-Having knowledge on objectives of educational } \\
\text { policy. } \\
\text { 7-Building experiences and learn. } \\
\text { 8-Involving in students' activities and organization's } \\
\text { vision and mission. }\end{array}$ & 6 \\
\hline 2 Skill & $\begin{array}{l}\text { 1-Applying a variety of curriculum management } \\
\text { skills. } \\
\text { 2-Coordinating and managing activities with parents } \\
\text { and community. } \\
\text { 3-Collaborating with others and using effective } \\
\text { communication skills and processes. } \\
\text { 4-Making effective decisions. } \\
\text { 5- Practicing appropriate interpersonal skills in }\end{array}$ & 6 \\
\hline
\end{tabular}




\begin{tabular}{|l|l|l|}
\hline & $\begin{array}{l}\text { educational context. } \\
\text { 6-Fostering mutually respectful and productive } \\
\text { relationships among colleagues }\end{array}$ & \\
\hline 3 Value & $\begin{array}{l}\text { 1- Models various leadership values and behaviors. } \\
\text { 2-Being committed to meet the needs of students. } \\
\text { 3-Displaying awareness on the diversity within the } \\
\text { classroom. } \\
\text { 4-Willing to take risk. } \\
\text { 5-Engaging others in organization improvement. } \\
\text { 6-Facing challenges. } \\
\text { 7-Perusing a life-long learning. } \\
\text { 8-Taking the initiative to work with the parents and } \\
\text { the community }\end{array}$ & 8 \\
\end{tabular}

\subsection{Teacher Professional Competency Questionnaire Items}

The items of the second part of the questionnaire rely on teacher professional competency constructed based on a study conducted by (Nichols, Stevenson, Hedberg \& Gillies, 2016). Some factors have enormous impact on teacher professional competencies, i.e. personal skills, professional skills, and pedagogical skills (see Table 3.6).

Table 3.6 Teacher Professional Competency

\begin{tabular}{|l|l|l|l|}
\hline \multicolumn{2}{|l|}{ Factor } & Focus & $\begin{array}{l}\text { Number of } \\
\text { Items }\end{array}$ \\
\hline 1 & $\begin{array}{l}\text { Pedagogical } \\
\text { skills }\end{array}$ & $\begin{array}{l}\text { 1-Incorporating a variety of strategies and techniques. } \\
\text { 2-Establishing didactic details clearly and concisely. } \\
\text { 3-Handling the progress of student. } \\
\text { 4- Offering feedback for the students. } \\
\text { 5-Identifying students and their diversity. }\end{array}$ & 5 \\
\hline 2 & Personal Skills & $\begin{array}{l}\text { 1-Being flexible. } \\
\text { 2-creative, 3-committed and 4- trustworthy. }\end{array}$ & \\
\hline 3 & $\begin{array}{l}\text { Professional } \\
\text { Skills }\end{array}$ & $\begin{array}{l}\text { 1-Subject knowledge. } \\
\text { 2- Knowledge of students. } \\
\text { 3- Teaching mythological approaches. } \\
\text { 4- Being fully aware of curriculum knowledge. } \\
\text { 5- Being aware of classroom organization technique. }\end{array}$ & \\
\hline
\end{tabular}

\subsection{Student Academic Achievement Items}

The student academic achievement variable has five dimensions: grades, language confidence, acquisition of skills and competencies, communication skills in English, and students' satisfaction towards teaching and learning processes (see Table 3.7). 
Table 3.7 Student Academic Achievement in English

\begin{tabular}{|l|c|l|c|}
\hline \multicolumn{2}{|l|}{ Dimensions } & Focus & $\begin{array}{c}\text { Number } \\
\text { of Items }\end{array}$ \\
\hline 1 & Grades & $\begin{array}{l}\text { 1-English language grades comparing to other } \\
\text { subjects' grades }\end{array}$ & 2 \\
\hline 2 & Language Confidence & $\begin{array}{l}\text { 1-Being confident to use English in/out of class. } \\
\text { 2-Being supported by their teacher to practice English. } \\
\text { 3-Fluency/ accuracy in L2 }\end{array}$ & 3 \\
\hline 3 & $\begin{array}{l}\text { Acquisition of Skills } \\
\text { and Competences }\end{array}$ & $\begin{array}{l}\text { 1-Teacher's encouragement. } \\
\text { 2-Communication with colleagues and teachers. } \\
\text { 3-Getting motivated to use L2 }\end{array}$ & 2 \\
\hline 4 & Communication Skills & $\begin{array}{l}\text { 1-Sharing individual views with many others. 2- } \\
\text { Effective communication with others. } \\
\text { 3-Teacher's communication skills. } \\
\text { 4-Teacher-student interaction and classroom } \\
\text { management }\end{array}$ & 4 \\
\hline 5 & Satisfaction & $\begin{array}{l}\text { 1-Students' level of satisfaction. Classroom } \\
\text { environment. }\end{array}$ & 4 \\
\hline
\end{tabular}

\subsection{Likert- Scale}

This study used an instrument-rated on a five-point Likert scale formulated by Simon (2003). The five-point scale is the most practical for most common purposes. The strength of an attitude is linear in a Likert-scale and forms the assumption where attitudes can be measured. Simon (2003) suggested that composite scales of five or more points certainly help define more precision, gradations of concentration and data on different dimensions of the response. The instrument of teacher leadership was measured via post-foundation students' responses on their teacher's leadership as follows: " 1- not at all", "2- once in a while", "3 -sometimes", "4- fairly often" and "5- frequently". The instrument of teacher professional competency was assessed through post foundation students' responses on their teacher's professional competency. The respondents' choices are rated on a five-point Likert scale as follows:"1- strongly disagree", "2- disagree", "3-neutral", "4- agree" and "5- strongly agree".

Internal validity was needed to show empirical evidence of the study tool. The use of a reliability test usually does this. Reliability is related to the consistency of an instrument. Although it is not possible to give a precise reliability calculation, an estimate of reliability can be done through different measures (Heale \& Twycross, 2015). There are three attributes of reliability which are: (i) internal consistency; (ii) stability and (iii) equivalence. Internal consistency is measured using item-to-total correlation, split-half reliability, Kuder-Richardson coefficient and Cronbach's $\alpha$. The most commonly used internal consistency measure is the Cronbach Alpha coefficient.It is considered the most suitable measurement of reliability when using Likert scales (Whitley, Kite \& Adams, 2013; Taherdoost, 2016). Many researchers agree on a minimum internal consistency coefficient of .70 (Whitley, Kite \& Adams, 2013; Taherdoost, 2016). The reliability coefficient (alpha) can range from 0 to 1. 0 represents an instrument full of errors. 1 represents a total absence of any errors. A reliability coefficient (alpha) of 0.7 or even higher is acceptable reliability (Bashir \& Marudhar, 2018).

For the purpose of the present study construct validity, Pearson Correlation Coefficient (PCC) is employed to confirm what dimensions each question in the assessment loads onto. It accurately estimates correlations among variables.

To determine the reliability and internal consistency of the instrument, the composite reliability is Cronbach's Alpha coefficient was employed. The scale's reliability is accepted as good if the coefficient is found equal or greater than 0.70 (Kilic, 2016). The data was calculated using the Statistical Package for the Social Sciences (SPSS) using the formula of summiting the items which go under one factor. 


\subsection{Data Analysis Procedure}

Data analysis is the way a researcher gains meaningful insights from a given data (Ruan \& Zhang, 2017). The researcher started with the data cleaning process to ensure the accuracy and consistency of the data collected. Having completed the questionnaire, the responses were carefully coded. Statistical Package for Social Sciences (SPSS, version 20) Program was used to analyze the data. SPSS is the most powerful program used in educational research to analyze data. According to (Şen, $2019, \mathrm{p}$. 21), "SPSS is a powerful tool that is useful in conducting data analysis". After entering the data into SPSS, a statistics specialist, approving the correct entry of the data, checked if there were any errors.

In line with the data analysis, the study showed that college students did agree that their English teachers have the necessary professional competencies in teaching the target language. The majority of the respondents agree that the teachers are wellversed in teaching, highly committed, and trustworthy. This finding supports the National Board for Professional Teaching Standards (2018) assertion that teachers are expected to manifest several competencies, including commitment, knowledge of the subject area, classroom management, creative thinking, and leadership. Hence, it is noteworthy that the respondents perceived their teachers as effective educators committed and knowledgeable. This teachers' commitment and knowledge of subject area is evident in showing the high means of a participant's statement: "my teacher has enough content knowledge of the subject", "my teacher clarifies the subject content well", "my teacher is flexible in teaching" and "my teacher has a high commitment to teaching." Moreover, the respondents perceived their teachers as trustworthy, as shown by the mean of 3.81 of this statement: "I trust my teacher when I discuss my performance with him/her." It must be noted that one of the teacher's professional competencies is (their) use of interesting teaching materials. This needs to be reconsidered as it was perceived to be not so evident (neutral) by the respondents. This insinuates that English teachers can still do something to make their teaching materials more fascinating and attractive to their students. In general, respondents perceived that their English teachers possess/acquire the appropriate professional competencies. This finding implies that students at vocational colleges perceive their English teachers as competent and highly qualified language teachers. This is demonstrated by the high means of these statements: "my teacher has enough content knowledge of the subject", "my teacher is able to incorporate a variety of strategies", "my teacher helps me understand my lessons easily" and "my teacher clarifies the content well." Furthermore, the respondents perceived that their English teachers show compassion to their students as illustrated by the high means results of these statements: "my teacher provides a continuous support to improve my English level", "my teacher provides feedback on my learning progress", "my teacher considers the differences among students' level" and" my teacher helps me understand the language easily." In terms of teachers' commitment, the results reveal that the respondents perceive the language teachers as committed professionals as supported by the high means result of this statement: "my teacher has high commitment to teaching." This finding supports the findings by Moqbel and Rao (2013), Gilakjani (2012),and Dayag (2016) that English teachers transform the academic environments through varied ways, and in the process, they gradually make language learning efficient, engaging and meaningful. The respondents also perceived that their English teachers provided them ample motivation and encouragement to enhance their English communication skills. They also conveyed that their English teachers apply appropriate assessment methods and classroom management techniques. This suggests that the respondents feel their English teachers facilitate their English language learning. This provides them genuine and ample opportunities to use the target language.

\section{Conclusion}

This study investigated how teacher leadership and professional competency affected student academic achievement in vocational Colleges in the Sultanate of Oman. The results revealed that if English teachers master the necessary leadership traits, they will perform better in language classrooms. This will thus enhance their English communication skills and eventually improve their academic achievement. Such a conclusion supports Leith Wood and associates (2004) assertion that teacher leadership positively influences students' academic progress. With the leadership behaviour of teachers, the students' learning and performance may improve as they become more confident and intrinsically motivated learners (Cheng, 1994; Pounder, 2008; Yildirim, Acar, Buli \& Sevine, 2008). Since the positive influence of teacher leadership on the students' academic achievement is well known, it is apparent that English teachers ought to pay attention to the whole class, initiate positive discussions and foster student-centred activities that would promote learner autonomy and help teachers keep in touch with the students' guardians. This lends credence to Wallace (2007) that students consider their teachers as leaders. Hence the former expect their teachers to lead them in terms of classroom engagement, class discussion and promoting student-centred learning activities. The present study revealed that students' academic achievement is positively correlated to teachers' professional competency. Correlation analysis reveals that teacher professional competency and students' academic achievement obtain a coefficient that has an associated probability value (.565), which is lower than 0.01 . Thus, the alternate hypothesis is accepted. The correlation analysis showed that the more the students agree that their English teachers master an appropriate professional competency level, the better their academic achievement is. These results insinuate that teachers should consider the interests and needs of their language learners in order to enhance their communication skills in the target language. Students' lack of confidence was pointed out as one of the Omani students' requirements to acquire (Al-Mahrooqi, 2015 \& Dayag, 2018). Hence, it is English teachers' responsibility to handle students' communication anxiety. In respect to 
enhancing college students' abilities in the English language on different metacognitive, communicative and pragmatic levels in vocational colleges in Oman, this research suggests that TESL scholars ought to recognize that the constant aim of teaching English to vocational college students should prioritize the real educational outcomes out of students' academic achievement. This can be achieved by cultivating teacher's cognitive, communicative and pragmatic professionalism through collaborative leadership practices. The present study claims that principal leadership has an impact on student accomplishment, though the effect is sometimes indirect byway of vocational college processes, instructional climate and classroom teachers. This outcome is especially influential when college instructors instil respect, cooperation and trust in ESL instructors. Hence, the involvement of college personnel and instructors in the college leadership and management is pivotal, since their involvement in decision making is positively associated with ESL instructors' commitment and satisfaction. The present study found that satisfactory student academic achievement requires various requirements and pre-conditions to pave the way for actual academic contribution at vocational colleges in the Sultanate of Oman. In other words, teacher-student relationship with teacher leadership and student academic performance cannot be performed without other related factors such as college environment, socio-economic factors related to college instructors, teaching and learning facilities. The present study found that the relationship between teacher leadership, professional competency and student outcomes is in fact based on substantial outcomes. These substantial outcomes require professionalism, which is an effective tool to improve English teaching quality for vocational college students. Such professional learning indeed "coincides with notions of learning to teach as a life-long undertaking, situated in practice" (Borko, Jacobs, \& Koellner, 2010, p.23) and within a professional culture of collaboration (Hargreaves, 2000). That is student academic accomplishment is directly associated with teacher leadership and professional competency as well as a long-term education (Meissel, Parr \& Timperley, 2016). The present study concluded that teacher leadership is not only impactful on boosting student academic accomplishment; it is of enormous effect on the mechanisms of learning processes beyond the conceptual educational paradigm. This, for instance, includes students' soft social skills as well as psycho-emotional intelligence. In fact, the study argues that motivational aspects of vocational college students in Oman are essential to consider by school management policies. To overcome poor academic performance by boosting student intrinsic and extrinsic motivation, the present study suggests that ESL college educators and instructors should enhance students' intrinsic motivation and (meta)cognition skills by assisting them to set endurable aims to facilitate learning acquisition and support constructive and meaningful engagement in academic activities. However, the present study shows different findings of that of (Ambusaidi \& Yang, 2019) in that subject matter knowledge, teacher certification, teaching experience, and pedagogical knowledge have been characterized as significantly connected with higher student accomplishment. The present study shows a very strong relationship between teacher occupational and leadership skills and student academic performance at the metacognitive and pedagogical levels. Different from the studies by (Ambusaidi \& Yang, 2019, Rice, 2003), the present study shows that teacher personal characteristics are found a key element in boosting student academic and non-academic achievement. The present study is consistent with (Clotfelter, Ladd \& Vigdor, 2007; Kalogrides, Loeb, and Béteille, 2013) in that teacher leadership and professional competency have a positive (co)relationship with student academic achievement in different regions in the world, i.e. Britain, France, China and Japan (Canales \& Maldonado, 2018). Such a conclusion validates the authenticity of the data collection, analysis measures and models of this study within the educational context of Oman. However, the present study differs in demonstrating how teacher individual differences affect student academic accomplishment of teachers and students belonging to the same culture and language. Having conducted and analyzed the data taken from seven different vocational colleges in Oman, the researcher strongly suggests that vocational colleges should adopt a unique organizational strategy that enables all college members to collaborate to accomplish organizational goals, which helps teachers and students learn through reciprocal cooperation.

\section{References}

[1] Al-Taneiji, S., \& Ibrahim, A. (2017). Practices of and roadblocks to teacher leadership in the United Arab Emirates' schools. International Education Studies, 10(6), 87-99.

[2] Ambusaidi, I., \& Yang, Y. (2019). The Impact of Mathematics Teacher Quality on Student Achievement in Oman and Taiwan. 1(2), 50-62.

[3] Akiba M, LeTendre GK, Scribner JP (2007). Teacher quality, opportunity gap, and national achievement in 46 countries. Educational Researcher, 36(7):369-387. doi:10.3102/0013189X07308739

[4] Hanushek and F. E. Hanushek, and S. Rivkin, "teacher quality", in Handbook of the economics of education, E. Welch (Eds.), vol. 2, Amsterdam, The Netherlands: North-Holland, 2006, pp. 1051- 1078.

[5] Karami-Akkary, R., \& Rizk, N. (2012). The TAMAM project: Shifting the paradigm of educational reform in the Arab world. Journal of International Education and Leadership, 2(3), 1-29. Retrieved from http://www.jielusa.org/

[6] Knight, S., "Evaluation of teacher quality", in Handbook on measurement, assessment, and evaluation in higher education, C. Secolsky (Ed.), New York: Routledge, 2012, pp. 584-592.

[7] Koedel, C., Parson, E., Podgursky, M., \& Ehlert, M. (2015). Teacher preparation programs and teacher quality: Are there real differences across programs? Education Finance and Policy, 10(4), 504-534.

[8] Korkmaz, S. (2017). Study of positivist and post-positivist views based on instructional design models and learning approaches. New Trends and Issues Proceedings on Humanities and Social Sciences, 3(3), 137-147. 
[9] Darling-Hammond (2015). Teacher quality and student achievement: A review of state policy evidence: Education Policy Analysis Archive, 8(1), pp. 1-44. //epaa.asu.edu/ojs/article/view/392.

[10] Wiley. D., \& Yoon, A. Teacher reports of opportunity to learn analyses of the 1993 California learning assessment system. Educational Evaluation and Policy Analysis, 17 (3), pp. 355-370, 1995.

[11] Zuzovsky., R. (2015). Teachers' qualification and their impact on student achievement. http://www.iea.nl/fileadmin/user upload/IRC/IRC 2008/Papers/IRC2008 Zuzovsky2.pdf. 